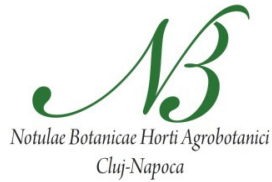

\title{
Phenotypic and Molecular Screening of Apple Genotypes to Woolly Apple Aphid Resistance
}

\author{
Saeid ABU-ROMMAN ${ }^{1 *}$, Mazen ATEYYAT ${ }^{2}$ \\ ${ }^{1}$ Department of Biotechnology; ${ }^{2}$ Department of Plant Production and Protection. Faculty of Agricultural Technology, Al-Balqa' Applied \\ University, Al-Salt, 19117,Jordan; ssadroman@yahoo.com ("corresponding author)
}

\begin{abstract}
Woolly apple aphid (WAA) is a major pest of apple orchards resulting in significant losses. In the present study, 22 apple (Malus domestica Borkh.) cultivars were tested in the filed for their relative resistance/susceptibility to WAA. These apple cultivars were found to respond differentially to WAA infestation. Based on tree infestation rating, cultivars were ranked into 6 relative resistance/susceptibility groups, as follows: immune - 'Golden Delicious', 'Delbarestivale', 'Golden Smoothie', 'Red Miracle' and 'Harmony'; resistant - 'Stark Gold', 'Early Gold' and 'Argi Gala'; moderately resistant - 'Evanee' and 'Black Stayman'; moderately susceptible - 'Vista Bella', 'Jonagold', 'Royal Gala', 'Jersey Mac', 'Granny Spur Type' and 'Summerred'; susceptible - 'Jonathan', 'Nagava 6, 'Florina', 'Red Chief and 'Gold Iralis'; highly susceptible - 'Fuji 6. Eight molecular markers linked to major WAA resistant genes (Er1, Er2, and Er3) were screened in apple cultivars using PCR. The markers NZms_EB145764, NZms_EB106753 and NZsc_E01 were ubiquitous in all cultivars under study, whereas, NZsn_O05 was absent. The results of other markers revealed distinct patterns of amplification among apple cultivars. No clear correlations can be made between the molecular data (marker presence and absence) and the phenotypic results (cultivar ranking). The differences among cultivars regarding WAA infestation can potentially be utilized by apple breeders and commercial growers to achieve effective, environmental-friendly, and low-cost pest control.
\end{abstract}

Keywords: cultivar, Eriosoma lanigerum, host plant resistance, infestation rating, Malus domestica, resistance, susceptibility

\section{Introduction}

Apple (Malus domestica Borkh.) is one of the most economically important fruit crops of the temperate zones of the world (Harris et al., 2002). Apple trees are usually attacked by several types of arthropod pests (Shoonhoven $e t$ al., 2005). Aphids (order Homoptera) are key pests in apple orchards worldwide (Bloomers, 1994; Prokopy and Croft, 1994; Beers et al., 2003). Aphid infestation in apple causes deformation of foliage and fruits. In addition, some aphid species can act as vectors for virus transmission and the release of their honeydew promotes the development of mold infestation (Beers et al., 2003; Blommers et al., 2004; Arbab et al., 2006).

The woolly apple aphid (WAA), Eriosoma lanigerum (Hausmann) (Hemiptera: Aphididae), is one of the most important aphid pests of apples in many of the world's apple growing regions (Hatton, 1937). WAA is becoming critical to the economics of apple industry in Jordan (Ateyyat and Antary, 2009; Ateyyat and Antary, 2010). WAA colonizes both the roots and the vegetative parts of apple trees (Alspach and Bus, 1999). This aphid pest overwinters in edaphic colonies on roots and produces its first instar nymphs (crawlers) in early spring (Thwaite and Bower, 1983). In spring, crawlers migrate upward and initiate new colonies in protected arboreal parts of the tree (Heunis and Pringle, 2006; Cockfield and Beers, 2007).

WAA infestation on roots resulted in the formation of hypertrophic galls which restricted water and nutrients uptake (Brown and Schmitt, 1990; Brown et al., 1995). Strong WAA infestations resulted from population outbreaks in the arboreal part of the tree, and can lead to reduction in canopy vigor due to premature defoliation, reduction in yield due to reducing fruit buds and splitting of fruit bearing wood, and reduction in fruit quality as a result of contaminating fruits with honeydew and sticky wool (Bertus, 1986; Brown and Schmitt, 1990; Brown et al., 1995; Pringle and Heunis 2001; Heunis and Pringle, 2006). WAA can be a significant phytosanitary issue for fruit exportation and an annoying pest during fruit harvesting (Cockfield and Beers, 2007).

WAA can be controlled chemically by organochloride and organophosphate insecticides (Cockfield and Beers, 2007; Shaw and Wallis, 2009). The international public trend toward the organic farming pushes against the use of chemical control of pests and prompting a need for integrated pest management (IPM). Therefore, adopting biological control through the introduction of the natural endoparasitoid Aphelinus mali is a good choice (Brown and Schmitt, 1994; Asante, 1997). However, its susceptibility to many of the insecticides and fungicides commonly used in 
apple orchards limits its use (Cohen et al., 1996, Nicholas et al., 2005; Rogers et al., 2011). Cultural control still offers a valuable mean to control WAA in apple orchards through the use of host-plant-resistance (HPR) strategy (Webster, 2003). HPR is an important easy-to-apply tactic of IPM (Beers et al., 1993) and can result from morphological factors and activation of defense and signaling responses (Pedigo, 2006). The presence of different apple cultivars and rootstocks provides the opportunity to select the most resistant genotypes available. Variation in susceptibility of apple cultivars to WAA infestations has been previously recorded (Asante et al., 1993; Deng et al., 1993; Sandanayaka et al., 2003). The development of new resistant lines and understanding their genetic background of WAA resistance are significant aspects for foresighted breeding strategies (Brown and Maloney, 2003; Sandanayaka et al., 2005). Molecular studies have been conducted for exploring the genetic basis of aphid resistance in apple. Some quantitative trait loci (QTLs) were identified associated with aphid resistance in apple. Molecular markers were discovered linked to QTLs for resistance to the rosy apple aphid, the leaf-curling aphid and the green apple aphid (Stoeckli et al., 2008). Recently, progresses have been achieved regarding the development of molecular markers associated with WAA resistance genes (i.e. Erl, Er2 and Er3) (Bus et al., 2008). Current phenotyping methods for selection of plants resistant to WAA are cumbersome, environment-dependent, and cannot distinguish plants containing combinations of resistance genes from those carrying a single gene (Bus et al., 2008). Therefore, screening for the presence of molecular markers linked to WAA resistance genes would be an alternative.

In the current research, different apple cultivars were screened phenotypically for their resistance to WAA infestation. Furthermore, a molecular study was performed for screening these cultivars for the presence of different molecular markers associated with Er1, Er2 and Er3 resistance genes.

\section{Materials and methods}

\section{Monitoring of WAA infestation and data analysis}

Monitoring part of the experiment was conducted at the Apple Genetic Complex in Ash-Shoubak Regional Center of Agriculture Research and Extension. The trees under investigations were trained under the central-leader system and were planted on Merton-Malling Series (MM) 106 rootstock. The experiment was conducted on 22 apple cultivars of different flowering time, fruit color, and time of fruit maturity.

WAA infestation was monitored in terms of aerial colonies formation. Monitoring was carried out every 2 weeks on five trees per cultivar for the duration of seven months from January to July. Each tree was rated on a 0-4 infestation rating scale, using a visual indexing technique and ratings modified from Bower (1987). Cultivars were ranked for their relative resistance/susceptibility to WAA based on the tree infestation rating according to Ateyyat and Al-Antary (2009) (Tab. 1).

Mean separation was performed by using Least Significant Differences test (LSD). All differences were
Tab. 1. Rating scale for the assessment of level of resistance based on infestation level of WAA

\begin{tabular}{ccc}
\hline Level of infestation (\%) & Scale & Resistance rating \\
\hline 0 & 0 & Immune \\
$1-15 \%$ & 0.5 & Highly resistant \\
$16-30 \%$ & 1 & Resistant \\
$31-50 \%$ & 1.5 & Moderately resistant \\
$51-65 \%$ & 2 & Moderately susceptible \\
$66-80 \%$ & 2.5 & Susceptible \\
$81-90 \%$ & 3 & Highly susceptible \\
$91-100 \%$ & 4 & Very highly susceptible \\
\hline
\end{tabular}

compared at the $5 \%$ level $(p \leq 0.05)$ of significance and LSD test was used to separate means if significant differences found.

\section{Molecular analysis}

Healthy leaf tissues were collected from all cultivars under study and were stored at $-20^{\circ} \mathrm{C}$ for DNA extraction. Leaf tissues were ground into a fine powder in liquid nitrogen using a mortar with a pestle. Template DNA was extracted using a modified CTAB method (Saghi-Maroof $e t$ al., 1984). For each cultivars, about $0.5 \mathrm{~g}$ of fine leaf powder were suspended in $2 \mathrm{ml}$ of DNA extraction buffer $(0.22 \mathrm{M}$ EDTA pH 8, $0.8 \mathrm{M} \mathrm{NaCl}, 0.14 \mathrm{M}$ sorbitol, $0.2 \mathrm{M}$ Tris$\mathrm{HCl} \quad \mathrm{pH} \quad 8, \quad 0.8 \% \quad \mathrm{CTAB}, \quad 0.5 \%$ SDS, $0.5 \% \quad \beta-$ mercaptoethanol). About $500 \mu \mathrm{l}$ of chloroform were added to the suspension and mixed vigorously. The mixture was incubated at $65^{\circ} \mathrm{C}$ for $40 \mathrm{~min}$ and then centrifuged. The supernatant was taken and the DNA was precipitated by the addition of $500 \mu \mathrm{l}$ of isopropanol. The DNA was collected by centrifugation and the DNA pellet was washed twice with $70 \%$ ethanol. DNA pellets were dissolved in 100 $\mu \mathrm{l} \mathrm{TE}$ buffer (10 mM Tris-HCl, $1 \mathrm{mM}$ EDTA pH 8). The concentration and purity of DNA were assayed using UV spectrometry at 260 and $280 \mathrm{~nm}$.

PCR reactions were performed in purpose of screening the presence of eight different molecular markers linked to major WAA resistance genes (Erl, Er2, and Er3). The molecular markers were amplified using specific primers as suggested by Bus et al. (2008) (Tab. 2). All PCR amplification reactions were performed in a total volume of $25 \mu \mathrm{l}$. The PCR reaction mixture contained about $300 \mathrm{ng}$ of template DNA, 12.5 $\mu \mathrm{l}$ of 2x PCR master mix solution (iNtRON, Korea), 5 pmole of each primer and distilled $\mathrm{H}_{2} \mathrm{O}$ was added to make up the final volume. Markers NZsc_GS327, NZsc_O05, NZsc_E01 and NZsc_A01 were amplified with an annealing temperature of $60^{\circ} \overline{\mathrm{C}}$ and an extension time of $2 \mathrm{~min}$. Whereas, a touchdown PCR cycling regime was employed to amplify the rest of the markers with annealing temperature decreasing from $65^{\circ} \mathrm{C}$ to $60^{\circ} \mathrm{C}$ in decrements of $0.5^{\circ} \mathrm{C}$ per cycle.

PCR amplified products were separated and analyzed by electrophoresis on 1-2\% agarose gels stained with ethidium bromide. As molecular weight markers, 1-kp and 100-bp DNA ladders (New England Biolabs) were used. Results were scored for the presence and absence of the molecular markers. 
101

Tab. 2. Primer sequences and product length in base pairs of the molecular markers used in the present study

\begin{tabular}{ccccr}
\hline \multirow{2}{*}{ Marker name } & WAA resistance & \multicolumn{2}{c}{ Primer sequence $\left(5^{\prime} \rightarrow 3^{\prime}\right)$} & Product size \\
\cline { 3 - 4 } & gene & Forward & Reverse & \\
\hline NZsc_C20 & $E r l$ & TCTCTAACTCAATAACTCCCAAGAC & ACTTCGCCACCATTATCACTCCTGA & 2,000 \\
NZss_GS327 & $E r l$ & GCCAAGCTTCAATGTCGGAGTAGAT & CAAGCTTCCCCTAAGGCTATTGCCA & 1,600 \\
NZsc_O05 & $E r l$ & CCCAGTCACTAACATAATTGGCACA & CCCAGTCACTGGCAAGAGAAATTAC & 1,700 \\
NZms_EB145764 & $E r 2$ & TTCCAGCGATCCAAAACAAT & GCTCAGGAACACCTCGTTCT & 198 \\
NZsn_O05 & $E r l / E r 3$ & AACGTCATGTCAATAT & CCCAGTCACTGGCAAGAGAAATTAC & 880 \\
NZms_EB106753 & $E r l / E r 3$ & TCTGAGGCTCCCAAGTCC & TAGGAGCAGAAGAGGTGACG & 175 \\
NZsc_E01 & $E r 3$ & CCCAAGGTCCGAACACAAATGAGAG & CCCAAGGTCCAAAACTATCCCGAAG & 1,350 \\
NZsc_A01 & $E r 3$ & CAGGCCCTTCAGCAAAGAGGTGTCT & CAGGCCCTTCACTACTAATAAGAAC & 1,250
\end{tabular}

\section{Results and Discussion}

WAA is a potentially detriment pest to apple production worldwide causing a range of diverse injuries to apple trees and fruits (Brown et al., 1995). Management of WAA infestations using apple cultivars and rootstocks is considered an important strategy. In the present study, apple cultivars responded differentially to WAA infestation. Results represented in Fig. 1 showed that the highest number of WAA colonies were recorded for five cultivars, namely; 'Fuji 6', 'Jonathan', 'Red Chief, 'Gold Iralis', and 'Nagava 6'. Out of the 22 apple cultivars under investigation, cultivars 'Golden Delicious', 'Delbarestivale', 'Golden Smoothie', 'Red Miracle', and 'Harmony' were recorded with complete absence of WAA colonies.

Cultivars ranking based on the tree infestation rating were followed as suggested by Ateyyat and Al-Antary (2009). According to this ranking, 'Fuji 6' was recorded as highly susceptible cultivar, while 'Golden Delicious',

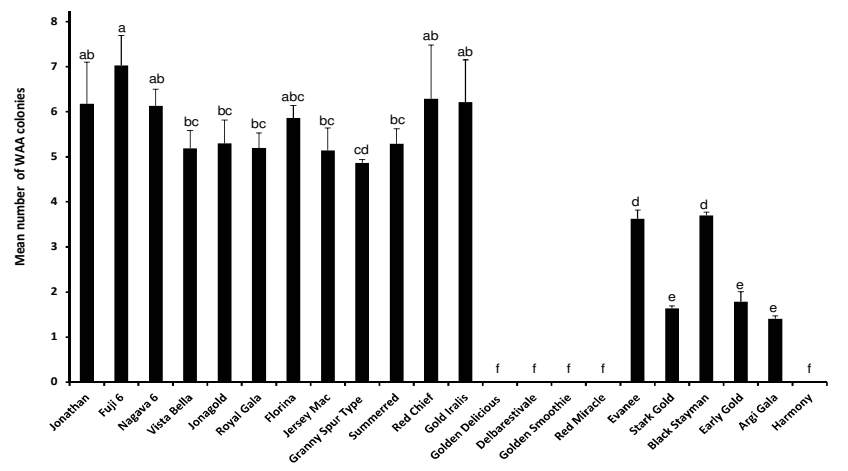

Fig. 1. Mean numbers of WAA colonies per $15 \mathrm{~cm}$ length limb of unsprayed apple cultivars. Means with different letters are significantly different according to LSD

'Delbarestivale', 'Golden Smoothie', 'Red Miracle' and 'Harmony' were considered as immune (Fig. 2). Ateyyat and Al-Antary (2009) reported that WAA adults failed to colonize on 'Harmony' and no infestations were recorded either on its roots or shoots.

Moreover, the present study yielded three resistant ('Stark Gold', 'Early Gold' and 'Argi Gala'), two moderately resistant ('Evanee', and 'Black Stayman'), six moderately susceptible ('Vista Bella', 'Jonagold', 'Royal Gala', 'Jersey Mac', 'Granny Spur Type' and 'Summerred'), and five susceptible ('Jonathan', 'Nagava 6', 'Florina', 'Red Chief and 'Gold Iralis') cultivars. 'Royal Gala' is well-known cultivar for its susceptibility to WAA infestation. This cultivar was reported to display a range of WAA susceptible characteristics including high level of settlement, high survival rate, and long periods of phloem feeding (Sandanayaka et al., $2005)$. None of the 22 apple cultivars tested were ranked as highly resistance or very highly susceptible (Fig. 2). Various WAA-resistant rootstocks were previously developed from the immune cultivars 'northern Spy', including the Malling-Merton rootstocks of the 100 series (Webster, 2003). These rootstocks may owe their resistance to high phenolic levels (Sen Gupta and Miles, 1975). However, some reports have indicated the breakdown of resistance of these rootstocks (Rock and Zeiger, 1974; Ateyyat and Al-Antary, 2009).

Three major WAA resistant genes (Erl, Er2, and Er3) have been characterized and used in apple resistance breeding (Bus et al., 2008). Eight different molecular markers linked to these genes were screened by PCR in the apple cultivars under investigation (Tab. 3). The marker NZms_EB145764, which is linked to Er2 resistant gene, is

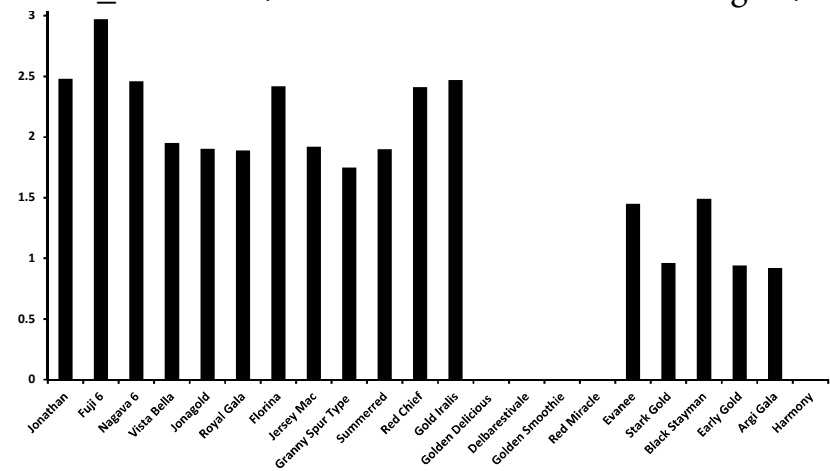

Fig. 2. Shoot infestation rating (0-4) of WAA on un-sprayed apple cultivars

present in all cultivars. The same is applicable to NZms_EB106753 and NZsc_E01 which are linked to $E r 1 / E r 3$ and Er3, respectively. On the other hand, NZsn_O05 marker is absent from all cultivars under study. NZsc_A01 (linked to Er3) is present in all cultivars except for 'Fuji 6', 'Jonagold', and 'Granny Spur Type'. Sandanayaka et al. (2003) reported that Er3 resistant gene was carried by the cultivar 'Aotea' and this type of mediated resistance was overcome by WAA, indicating that Er3mediated resistance is distinct from $\operatorname{Er} 1$ and $\operatorname{Er} 2$.

'Early Gold' is the only cultivar containing NZsc_C20 marker which is linked to Erl. The marker NZsc_GS327 is present in 11 cultivars, namely; 'Granny Spur Type', 
Tab. 3. Detection of molecular markers linked to WAA resistance genes in different apple cultivars. Plus (+) indicates the presence of a marker

\begin{tabular}{|c|c|c|c|c|c|c|c|c|}
\hline \multirow[b]{2}{*}{ Cultivars } & \multicolumn{8}{|c|}{ Markers linked to WAA resistance genes } \\
\hline & NZsc_C20 & NZsc_GS327 & NZsc_O05 & NZms_EB145764 & NZsn_O05 & NZms_EB106753 & NZsc_E01 & NZsc_A01 \\
\hline 'Jonathan' & - & - & - & + & - & + & + & + \\
\hline 'Fuji 6' & - & - & - & + & - & + & + & + \\
\hline 'Nagava 6' & - & - & - & + & - & + & + & + \\
\hline 'Vista Bella' & - & - & - & + & - & + & + & + \\
\hline 'Jonagold' & - & - & - & + & - & + & + & + \\
\hline 'Royal Gala' & - & - & - & + & - & + & + & + \\
\hline 'Florina' & - & - & - & + & - & + & + & + \\
\hline 'Jersey Mac' & - & - & - & + & - & + & + & + \\
\hline 'Granny Spur Type' & - & + & - & + & - & + & + & - \\
\hline 'Summerred' & - & + & - & + & - & + & + & + \\
\hline 'Red Chief' & - & + & - & + & - & + & + & + \\
\hline 'Gold Iralis' & - & - & + & + & - & + & + & + \\
\hline 'Golden Delicious' & - & + & - & + & - & + & + & + \\
\hline 'Delbarestivale' & - & + & - & + & - & + & + & + \\
\hline 'Golden Smoothie' & - & + & - & + & - & + & + & + \\
\hline 'Red Miracle' & - & + & + & + & - & + & + & + \\
\hline 'Evanee' & - & + & + & + & - & + & + & + \\
\hline 'Stark Gold' & - & + & + & + & - & + & + & + \\
\hline 'Black Stayman' & - & + & + & + & - & + & + & + \\
\hline 'Early Gold' & + & - & + & + & - & + & + & + \\
\hline 'Argi Gala' & - & - & + & + & - & + & + & + \\
\hline 'Harmony' & - & + & + & + & - & + & + & + \\
\hline
\end{tabular}

'Summerred', 'Red Chief, 'Golden Delicious', 'Delbarestivale', 'Golden Smoothie', 'Red Miracle, 'Harmony', 'Stark Gold', 'Black Stayman', and 'Evanee'. NZsc_O05 marker is linked to $\mathrm{Erl}$ resistant gene and is present in the following eight cultivars: 'Harmony', 'Red Miracle', 'Evanee', 'Stark Gold', 'Black Stayman', 'Early Gold', 'Argi Gala', and 'Gold Iralis'. 'Northern Spy' and 'Robusta 5' are two WAA resistant genotypes and were reported to carry $E r l$ and $E r 2$ resistant genes, respectively (King et al., 1991). These genotypes possessed short duration of phloem ingestion suggesting the presence of resistant factors in their phloem tissues. A previous report indicated that the expression of resistance conditioned by $E r l$ increased with tree maturity, while resistance conditioned by $E r 2$ was high at earlier growth stages (Sandanayaka et al., 2003).

Although no clear correlations can be made between the molecular data (marker presence and absence) and the phenotypic results (cultivar ranking), the results of the current study indicated that resistance/susceptibility to WAA infestations varied among apple cultivars. These differences among cultivars can potentially be utilized by commercial apple growers to achieve effective pest control which in turn will reduce input costs and increase profitability.

Further studies are required to understand the mechanisms of responses/defense among different apple cultivars to WAA infestation. Such studies might employ the analysis of traits related to (i) pest-deterrent or repellent secondary metabolites, (ii) defense-related enzymes, and (iii) differential expression of defense genes. These traits may be utilized in the future as marker traits to select for resistance to WAA.

\section{Acknowledgement}

The authors greatly appreciate the technical assistance of Ahmad Sharab. This project was funded by Abdul Hameed Shoman Foundation.

\section{References}

Alspach PA, Bus VG, Bus M (1999). Spatial variation of woolly apple aphid (Eriosoma lanigerum Hausmann) in a genetically diverse apple planting. New Zeal J Ecol 23:39-44.

Arbab A, Kontodimas, DC, Sahragard A (2006). Estimating development of Aphis pomi (DeGeer) (Homoptera: Aphididae) using linear and nonlinear models. Environ Entomol 35:1208-1215.

Asante SK (1997). Natural enemies of the woolly apple aphid, Eriosoma lanigerum (Hausmann) (Hemiptera: Aphididae): a review of the world literature. Plant Prot Quart 12:166-170.

Asante SK, Danthanarayana W, Cairns SC (1993). Spatial and temporal distribution patterns of Eriosoma lanigerum (Homoptera: Aphididae) on apple. Environ Entomol 22:1060-1065.

Ateyyat MA, Al-Antary TM (2009). Susceptibility of nine apple cultivars to woolly apple aphid, Eriosoma lanigerum (Homoptera: Aphididae) in Jordan. Int J Pest Manage 55(1):79-84.

Ateyyat MA, Al-Antary TM (2010). Population Trends of Woolly Apple Aphid, Eriosoma lanigerum and its Parasitoid, Aphelinus mali on two Apple Cultivars in Jordan. Jordan J Agri Sci 6(3):333-341.

Beers EH, Brunner JF, Willett MJ, Warner GM (1993). Orchard Pest Management: A Resource Book for the Pacific Northwest. Good Fruit Grower, Yakima, WA.

Beers EH, Suckling DM, Prokopy RJ, Avilla J (2003). Ecology and management of apple arthropod pests, p. 489-514. In: Ferree DC, Warrington IJ (Eds.). Apples: Botany, Production and Uses. CABI Publishing, Wallingford, UK. 
103

Bertus AL (1986). Sooty Mould. Agfact H1.AB.5, 2nd edn. Department of Agriculture NSW, Australia.

Blommers LHM (1994). Integrated pest-management in European apple orchards. Annu Rev Entomol 39:213-241.

Blommers LHM, Helsen HHM, Vaal FWNM (2004). Life history data of the rosy apple aphid (Dysaphis plantaginea Pass.) (Homoptera, Aphididae) on plantain and as migrant to apple. J Pest Sci 77:155-163.

Bower CC (1987). Control of San José scale (Comstockaspis perniciosus (Comstock) (Hemiptera: Diaspididae) and woolly aphid (Eriosoma lanigerum (Hausmann) (Hemiptera: Pemphigidae) in an integrated mite control program. Plant Prot Quart 2:55-58.

Brown SK, Maloney KE (2003). Genetic improvement of apple: breeding, markers, mapping and biotechnology, p. 31-61. In: Ferree DC, Warrington IJ (Eds.). Apples: Botany, Production and Uses. CABI Publishing, Wallingford, UK.

Brown MW, Schmitt JJ (1990). Growth reduction in nonbearing apple trees by woolly apple aphids (Homoptera, Aphididae) on roots. J Econ Entomol 83:1526-1530.

Brown MW, Schmitt JJ (1994). Population dynamics of woolly apple aphid (Homoptera: Aphididae) in West Virginia apple orchards. Environ Entomol 23:1182-1188.

Brown MW, Schmitt JJ, Ranger S, Hogmire HW (1995). Yield reduction in apple by edaphic woolly apple aphid (Homoptera, Aphididae) populations. J Econ Entomol 88:127-133.

Bus VGM, Chagné D, Bassett HCM, Bowatte D, Calenge F, Celton J-M, Durel C-E, Malone M. T, Patocchi A, Ranatunga AC, Rikkerink EHA, Tustin DS, Zhou J, Gardiner SE (2008). Genome mapping of three major resistance genes to woolly apple aphid (Eriosoma lanigerum Hausm.). Tree Genet Genom 4:223-236.

Cockfield SD, Beers EH (2007). Biology and management of woolly apple aphid, Eriosoma lanigerum (Hausmann), in Washington State, pp. 37-42. In: IOBC WPRS Bulletin 30(4):37.

Cohen H, Horowitz AR, Nestel D, Rosen D (1996). Susceptibility of the woolly apple aphid parasitoid, Aphelinus mali (Hym: Aphelinidae), to common pesticides used in apple orchards in Israel. Entomophaga 41:225-233.

Deng JQ, Rui GS, Guan YT., Yu YQ, Zhang D, Hong JY, Deng JQ, Rui-GS, Guan YT, Yu YQ, Zhang DM, Hong JY (1993). The selection of an apple stock line, Siberian crabapple Jin 67, immune to the woolly apple aphid. Acta Phytophyl Sin 20(3):217-222.

Harris SA, Robinson JP, Juniper BE (2002). Genetic clues to the origin of the apple. Trends Genet 18(8):426-430.

Hatton RG (1937). The problems raised by the woolly aphis (Eriosoma lanigerum) of the apple - a case for team research. Ann Appl Biol 24:169-210.

Heunis JM, Pringle KL (2006). Field biology of woolly apple aphid, Eriosoma lanigerum (Hausmann), and its natural enemy, Aphelinus mali (Halderman), in apple orchards in the Western Cape province. Afr Entomol 14:77-86.

King GJ, Alston FH, Battle I, Chevreau E, Gessler C, Janse J, Lindhout P, Manganaris AG, Sansavini S, Schmidt H, Tobutt KR (1991). The 'European Apple Genome Mapping Project' developing a strategy for mapping genes coding for agronomic characters in tree species. Euphytica 56:89-94.

Nicholas AH, Spooner-Hart RN, Vickers RA (2005). Abundance and natural control of the woolly aphid Eriosoma lanigerum in an Australian apple orchard IPM program. BioControl 50:271-291.

Pedigo LP (2006). Entomology and Pest Management. Prentice Hall, Saddle River, NY.

Pringle KL, Heunis JM (2001). Woolly apple aphid in South Africa: biology, seasonal cycles, damage and control. Decid Fruit Grower 51:22-23.

Prokopy RJ, Croft BA (1994). Apple insect pest management, p. 543-585. In: Metcalf RL, Luckman WH (Eds). Introduction to Insect Pest Management. John Wiley \& Sons Ltd., New York.

Rock G, Zeiger D (1974) Woolly apple aphid infests Malling and Malling-Merton rootstocks in propagation beds in North Carolina. J Econ Entomol 67:137-138.

Rogers DJ, Sharma N, Stretton DC, Walker JTS (2011). Toxicity of pesticides to Aphelinus mali, the parasitoid of woolly apple aphid. New Zeal Plant Prot 64:235-240.

Saghai-Maroof MA, Soliman KM, Jorgensen RA, Allard RW (1984). Ribosomal DNA spacer-length polymorphisms in barley: Mendelian inheritance, chromosomal location and population dynamics. Proc Natl Acad Sci USA 81:8014-8018.

Sandanayaka WRM, Bus VGM, Connolly P, Newcomb R (2003). Characteristics associated with woolly apple aphid Eriosoma lanigerum, resistance of three apple rootstocks. Entomol Exp Appl 109:63-72.

Sandanayaka WRM, Bus, VGM, Connolly P (2005). Mechanisms of woolly aphid [Eriosoma lanigerum (Hausm.)] resistance in apple. J Appl Entomol 129:534-541.

Schoonhoven LM, van Loon JJ, Dicke M (2005). Insect-Plant Biology. Oxford University Press, Oxford, UK.

Sen Gupta GC, Miles PW (1975) Studies on the susceptibility of varieties of apple to the feeding of two strains of woolly aphid (Homoptera) in relation to the chemical content of the tissues of the host. Aust J Agric Res 26:157-168.

Shaw PW, Wallis DR (2009). Early-season use of insecticides for management of woolly apple aphid (Eriosoma lanigerum) in Nelson apple orchards. New Zeal Plant Prot 62:291-295.

Stoeckli S, Mody K, Gessler C, Patocchi A, Jermini M, Dorn S (2008). QTL analysis for aphid resistance and growth traits in apple. Tree Genet Genom 4:833-847.

Thwaite WG, Bower CC (1983). Woolly Aphid. Agfact H4. AE.3. NSW Agriculture, Orange, Australia.

Webster AD (2003). Breeding and selection of apple and pear rootstocks. Acta Hort 622:499-512. 